\title{
A Study on the Teaching Mode of "Mechanical Foundation" With the Integration of Curriculum Ideology and Accreditation
}

\author{
Xiangyang Jin*, Shasha Wang, Shuang Meng \\ School of Light Industry \\ Harbin University of Commerce \\ Harbin, China
}

\author{
Lili Zhao, Jing Lin, Jiang Chen \\ School of Light Industry \\ Harbin University of Commerce \\ Harbin, China
}

\author{
Guiwen Yu, Bin Fu, Jiang Chang, Xue Gong \\ School of Light Industry \\ Harbin University of Commerce \\ Harbin, China
}

\begin{abstract}
The combination of certification concept and course education can effectively improve the quality of talent training. This paper analyzes the characteristics of engineering courses, the teaching status of course education of engineering teachers, and the characteristics of engineering education certification system. This paper puts forward the method of integrating the "student-centered" concept, the "outputoriented" concept, the "continuous improvement" concept, which helps the students' achievements of the comprehensive development of moral, intellectual, physical, aesthetic and labor, the evaluation and the ideological and political improvement of the curriculum. Taking the "mechanical foundation" course as an example, this paper analyzes the purpose and significance of incorporating ideological and political education into the course teaching, and explores the path of incorporating ideological and political education into the course teaching of engineering major. Put the ideological education into the curriculum content, teaching methods and evaluation methods into, sets up the mechanism of coordinated cooperation of education, with the help of online resources, through the campus off-campus, class, inferior approach the implementation of course education, improves the students' humanities accomplishment and mental state, promotes the formation of good style of study, reflects the ideological moral education actual effect. As a reference in engineering courses, this paper provides ideological instruction for course through engineering education philosophy.
\end{abstract}

Keywords-course education; professional certification; mechanical foundation; teaching mode

\section{INTRODUCTION}

It is the fundamental task of teaching to impart knowledge and solve doubts. How to bring "preaching" and "imparting" into students' mind is a problem we are facing. The professional curriculum contains rich moral education elements and ideological and political content, which is a beneficial supplement to the traditional ideological and political

Heilongjiang Provincial Higher Education Teaching Reform Research Key Commissioned Project (Project No.:GZ20180027, SJGZ20190026); Heilongjiang Provincial Higher Education Teaching Reform Research Project (Project No.: SJGY20180247). curriculum. By making the two complementary to each other, the organic unity of knowledge transmission and quality improvement can be better realized. At the same time, the establishment of an output-oriented education system with output implementation as the main line and evaluation mechanism as the bottom line in combination with engineering education professional certification can better integrate ideological and political elements into students' professional knowledge, thus achieving a double harvest of "preaching" and "imparting".

\section{STATUS ANALYSIS}

\section{A. Difficulties in Integrating Ideological and Political Courses into Engineering Courses}

Strong logic, mathematics of engineering course, analyzing the issue of whether scientific, or engineering problem solving, cannot leave the mathematics modeling and deduction, strong logicality, with "mechanical foundation" course as an example, the main content includes graphics, structure design and mechanics analysis, error precision, heat treatment and so on course content, teaching process mainly principle is introduced, the formula derivation, analysis and calculation and experimental verification. There are some difficulties in the integration of the rational thinking characteristics of engineering courses and the perceptual thinking which is biased towards emotion and responsibility. Engineering courses often focus on indoctrination over interaction, acceptance over thinking, examination over emotion, which makes it difficult to achieve the expected effect of deliberate intervention of ideological and political elements in class.

\section{B. The Ideological and Political Role of Professional Teachers is Inadequate}

The template is used to format your paper and style the text. All margins, column widths, line spaces, and text fonts are 
prescribed; please do not alter them. You may note peculiarities. For example, the head margin in this template measures proportionately more than is customary. This measurement and others are deliberate, using specifications that anticipate your paper as one part of the entire proceedings, and not as an independent document. Please do not revise any of the current designations. Teachers assume the dual responsibility of teaching knowledge and guiding people. They should impart knowledge and guide thoughts together. Under the influence of fixed thinking, it is believed that ideological and political education is generally completed by student work teams such as secretaries and part-time instructors, and professional teachers only impart professional knowledge. Lead to professional teachers ignore the ideological and political education in the teaching process, and the related indepth understanding of the political education theory and the knowledge system, can't find the specialized knowledge and professional teachers play to the ideological and political education function of combining site, a lot of professional knowledge and teaching, moral education in the material has not been mining work of students and teachers in education failed to form resultant force [1]

\section{Characteristics of Engineering Education Professional Certification System}

How to make engineering course teaching not only meet the higher requirements of engineering education certification, but also integrate ideological and political elements into it "subtly and quietly" has become an urgent problem to be solved. Engineering education accreditation mainly focuses on three aspects: student center, output orientation and continuous improvement. It emphasizes following the growth and development law of engineering talents, taking students' learning effect as the guide, allocating teaching resources according to the core competence and quality requirements of social demands, organizing and implementing curriculum teaching, emphasizing all-round evaluation of teaching process, improving teaching links according to the evaluation results, and promoting the continuous improvement of talent cultivation quality [2].

Therefore, based on the characteristics of engineering course, this paper puts forward the implementation path of combining engineering course philosophy with professional certification. From ideological elements according to the characteristics of engineering course, the refining of the top design, certification, training scheme aspects such as the core ideas for education into the breakthrough point, aimed at students eventually harvest and quality promotion, pay attention to the political education implementation method of "quiet", relying on the closed-loop management measures of continuous improvement and improvement of effectiveness, let strengthen moral educate and cultivate people to lead in ideological and political courses, in the general course infiltration, deepening in the professional courses.

\section{EXTRACTION AND REFINEMENT OF IDEOLOGICAL AND POLITICAL ELEMENTS}

The engineering Education Certificate divides the target area of each course into three levels: knowledge, ability and quality. The integration of curriculum thought and politics is mainly reflected in helping students improve their ability and quality. Curriculum ideology provides an effective way for the realization of curriculum objectives of specialized courses. The support provided by curriculum ideology for the realization of curriculum objectives can be summarized as following:

- Philosophical thinking: The end of science is philosophy. Philosophical thinking takes the whole world as its research object, and its conclusions are of comprehensive and universal significance, leading and guiding scientific research and technological renewal [3]. When the technological transformation and progress meet the bottleneck, the indirect and abstract philosophical thinking with the method of logical deduction can often break through the clouds and see the light of day.

- Scientific thinking: Scientific thinking takes the specific field as the research object and is experimental and empirical thinking based on experimental methods. Its logical rules mainly include inductive logic and deductive logic, and analysis methods mainly include qualitative analysis, quantitative analysis, causal analysis and system analysis. By cultivating scientific thinking through curriculum ideology and politics, students can master correct thinking and working methods, improve their ability of identification, form a scientific world outlook and methodology, and finally enable students to make creative innovation and creation with existing knowledge.

- Engineering consciousness: Engineering consciousness mainly includes quality and safety consciousness, environmental protection and efficiency consciousness, management and legal consciousness, standardization consciousness, responsibility and team consciousness, etc. [4]. By cultivating engineering consciousness through ideological and political courses, students can think about engineering problems comprehensively and establish a harmonious relationship between man and nature, man and society, engineering and environment in an all-round way. Practice scientific engineering concept, put scientific research innovation and technological transformation in the social environment for comprehensive consideration, to produce quality products in harmony with social development.

- Craftsman spirit: "Craftsman spirit" is the outstanding performance of pursuing perfection and continuous improvement. Craftsman spirit means focus, innovation, dedication, lean, ordinary and other excellent qualities. Through the curriculum ideological and political training craftsman spirit, let the students develop the courage to study and forge ahead, the advanced standards of perseverance, never forget the 
beginning of solid work, indifferent to fame and wealth and willing to contribute to the excellent quality.

- Core socialist values: In the prevention and control of the epidemic, some Western media treat China with "double standards", block and suppress our high-tech enterprises in the field of technology, and public opinion habitually "demonize" China; Some of China's "we media" lack effective supervision, and big Internet Users spread false information to make trouble. Through education to foster students practice the socialist core values, and consolidate Marxist guiding status of ideology in the student thought, lead the students to set up the "patriotic", "rich" countries value goal and "dedicated", "integrity" personal value goal, through personal quality promote all-round social progress.

Through the course of ideological infiltration and blend in, can promote the formation of good style of study, learning to avoid the utilitarian, who understand and learn and how to learn, for specific learning goals, inspire students' inner of professional identity and sense of responsibility, according to their own interest to adjust the direction of the study, with their own efforts to make up for the countries in the field of highend, high-tech project, better realize their life values.

\section{CURRICULUM IdEOLOGICAL AND POLITICAL INTEGRATION INTO ENGINEERING EDUCATION PROFESSIONAL CERTIFICATION}

Engineering education professional certification "universal standard" contains seven first-level indicators, learn respectively Students, training objectives, graduation requirements, continuous improvement, curriculum system, faculty, support conditions. To strengthen the curriculum ideology of moral education, it is necessary to start from the revision of top-level training program, and then integrate the education system certified by engineering education into the curriculum.

\section{A. The Concept of "Student-centered" Persists in Cultivating People Through Virtue}

The student-centered teaching philosophy emphasizes that the main body of the classroom is the student, and teachers and various teaching resources should effectively cooperate with each other for the purpose of improving students' ability and quality [5]. The key criterion to evaluate classroom teaching is to see the student's harvest, not just the teacher's performance. Moral cultivation is the core of all the students' qualities.

Among the indicators of "students" in the training program, strengthen moral education and guide students to establish socialist core values; In the index of "curriculum system", the professional curriculum system should regard cultivating people with morality as the fundamental teaching task, combine ideological and political elements with curriculum ideological and political elements organically, and realize the all-round cultivation of the whole staff; Classroom teaching is transformed from the paradigm of "teaching" to the paradigm of "learning", and flipped classroom, seminar teaching, mixed teaching and project-based teaching are introduced more.

Taking mechanical drawing as an example, in addition to cultivating students' basic ability to draw and read mechanical engineering drawings, ideological and political contents such as cultivating engineering consciousness, standardization consciousness, innovation consciousness and rigorous and earnest working attitude are also added. By drawing mechanical graphics by hand and computer, students can not only master various drawing skills, but also cultivate their patience, carefulness and serious attitude, meticulous spirit of responsibility, as well as the compliance and implementation of national drawing standards.

\section{B. Implementation of the "Output-oriented" Concept: All Around Development of Moral, Intellectual, Physical, Aesthetics and Labor Education}

Output orientation takes the improvement of students' ability and quality as its foothold, carries out quality implementation, monitoring and evaluation of the whole process of talent training, and divides moral education into teaching objectives, teaching content and teaching process according to the output orientation. The overall improvement of students' knowledge, ability and accomplishment is the goal and requirement of course teaching, and the improvement of moral accomplishment is the core of course output

Guided by the promotion of moral education, the target of all-round development of morality, intelligence, physique, aesthetics and labor should be added into the target of "training target" of the training program. In the 12 index points decomposed by "graduation requirements", the content that students should establish and practice socialist core values should be strengthened.

Taking the mechanical principles in the course "Fundamentals of Mechanics" as an example, in addition to learning specialized knowledge such as institutional science and dynamics, how to make students more exposed to the scientific spirit involved in scientific principles is another problem that needs to be solved in class. In the course of teaching, relevant content related to mechanical principles can also be introduced, such as high-speed railway, C919 passenger plane and "Jiaolong" deep-sea exploration. Such manufacturing stories full of Chinese wisdom can enhance students' cultural confidence and road confidence in learning.

\section{Evaluation of the Concept of "Continuous Improvement" and Curriculum Policy Improvement}

The concept of continuous improvement takes output orientation as traction, reflects the teaching process according to the evaluation results, and provides guarantee for subsequent teaching improvement [6]. The improvement links include the continuous improvement of top-level mechanism, such as training objectives and graduation requirements, teaching process, evaluation criteria and their rationality, and teaching management, covering the whole process of undergraduate teaching from enrollment to employment, forming a complete closed loop [7]. 
Based on the theory and method of continuous improvement of engineering certification, the evaluation system of achievement degree of "curriculum thought and politics" is established. By introducing the concept and method of continuous improvement into the curriculum ideology and politics, tracing the implementation of each link in the education and teaching process, and reasonably evaluating whether the ideological and political goals have been achieved, the teaching links can be continuously improved, the degree of achievement of ideological and political goals can be continuously improved, and the organic unity of ideological and political education and knowledge system education can be achieved.

In the course ideological and political evaluation, formative evaluation should be carried out in a process-based manner. During the learning process, students' learning status and effect should be evaluated in a timely, dynamic and multiple way, and feedback should be given timely to improve students' learning [8]. Meanwhile, teachers should be assisted to perfect teaching methods. Curriculum ideological and political evaluation should be combined with the teaching content of specific specialized courses, integrate ideological and political education into the major, and carry forward the guidance of ideological and political education with professional content as the carrier. The evaluation of curriculum ideological and political learning effect can judge whether students' moral character has been improved through the solution of students' open problems.

Taking the mechanical design experiment part in the course Of "Foundation of Machinery" as an example, it aims to cultivate students' ability to take experimental cost, waste treatment, teamwork and excellence into consideration. While completing the experimental technical objectives. In the analysis of the results, can we be realistic and constantly improve, can we pay attention to the society, consider the harmonious relationship between man and nature, and can we draw conclusions based on facts and make reasonable explanations. Based on the principle that classroom assessment is the main body, behavior assessment is the feature, and process assessment is the focus [9], the final score assessment is conducted by combining peacetime learning process assessment with final exam results.

\section{CONCLUSION}

Engineering education professional certification education idea is not like a traditional education emphasizes the comparative evaluation between the students, but emphasize achieving students self-evaluation, under the background of engineering education accreditation course education to cultivate the engineering type talent as a fundamental task of having both ability and political integrity, not to test scores for students learning evaluation and class teaching goal only standard, let the university students develop comprehensively in the process of receiving skill training. Refined professional course the moral education function of the ideological elements and bearing, perfect the teaching case design, to translate strengthen moral education and cultivate people in the course of classroom teaching, through online, inside and outside of the classroom, campus off-campus multilevel evaluation system, promote education in the teaching effect, help students establish the correct moral concept, get rid of the impetuous mood, shouldering the task of realizing the national development and national rejuvenation.

\section{ACKNOWLEDGMENT}

At the point of finishing this paper, I'd like to express my sincere thanks to all those who have lent me hands in the course of my writing this paper. First of all, I'd like to take this opportunity to show my sincere gratitude to research project issues on epidemic prevention and control strategies and educational reflection in the context of COVID-19 in 2020, which subject got me thinking about this problem. Secondly, I'd like to express my gratitude to my team members who offered me references and information on time, without their help, it would be much harder for me to finish my paper.

\section{REFERENCES}

[1] ZHOU Yuepeng, DING Zhaoming, "Research on the main role of college teachers in promoting the construction of course education," Beijing education,Beijing,vol. 11, pp. 77-79, November 2018.(In Chinese).

[2] ZHANG Ning, "Exploration on the reform path of local higher engineering education under the background of engineering education certification," EDUCATION TEACHING FORUM,Shijiazhuang,vol. 40, no.10, pp.74-76, Oct,2016. (In Chinese).

[3] MI Jiangxia, "Give full play to the role of philosophy in cultivating college students' core qualities,'JOURNAL OF SOCIAL SCIENCE OF JIAMUSI UNIVERSITY, Jiamusi, vol.36, no.3, pp.100-102,June 2018. (In Chinese).

[4] LI Qiulian, "Connotation and construction of engineering awareness and engineering spirit," Journal of architectural education in institutions of higher learning, Chongqing, vol.22, no.2, pp.9-12, February 2013. (In Chinese).

[5] WANG Haiwen, LI Jie,WAN Xiaoxia,et al, "Research on Talent Cultivation Model of Four Innovative Education in Printing and Packaging Specialty," DIGITAL RINTING,Beijing, vol.201, no.3, pp.104-107, June 2019. (In Chinese).

[6] LIU Yanjun,DING Feng, "Discussion on the teaching reform mode of system identification," Education Modernization,Beijing, no.4, pp.6973,January 2018. (In Chinese).

[7] ZHANG Yonghai,DONG Huadong,YUE Liwen,et al, "Research and practice of continuous improvement strategy for process equipmen specialty oriented to engineering certification,'Teaching (higher education forum), Harbin,no.27, pp.34-35 ,September 2019. (In Chinese).

[8] ZHANG Haojun, "On the reform of college curriculum assessmen method based on formative evaluation," University Education,Nanning, vol.7, pp.180-182, July 2018. (In Chinese).

[9] LI Fang, "Discussion on teaching reform of foreign trade English documents for business English majors,"The exam week,Jilin,vol.91, pp.19-20,April 2011. (In Chinese) 